Історико-політичні проблеми сучасного світу: Збірник наукових статей. - Чернівці: Чернівецький національний університет, 2020. - T. 42. - C. 109-120

DOI: $10.31861 / \mathrm{mhpi} 2020.42 .109-120$

УДК: 327(489)
Modern Historical and Political Issues: Journal in Historical \& Political Sciences. - Chernivtsi: Chernivtsi National University, 2020. - Volume. 42. - pp. 109-120 DOI: $10.31861 / \mathrm{mhpi} 2020.42 .109-120$

\title{
Еволюція політики Данії у НАТО в другій половині ХХ ст.
}

Розглянуто трансформацію підходів Данії до блокової політики крізь призму реалізації безпекових пріоритетів країни. Виявлено суперечності в намаганні з боку Данії утримати баланс між статусом без'ядерної держави й необхідністю погодитися на присутність американської військової бази в Гренландії. 3'ясовано причини та особливості амбівалентного ставлення Данії до НАТО впродовж холодної війни. Наголошено на негативних наслідках данської «політики застережень» 1980-х рр. у НАТО для іміджу країни як надійного союзника. Розкрито причини переходу Данії до активної безпекової політики впродовж 1990-х рр. в контексті посилення Атлантизму. Проаналізовано характер участі Данії у реалізації безпекових ініціатив 3 боку міжнародного співтовариства та інтервенційної діяльності в рамках НАТО й ad-hoc-коаліцій на чолі зі США. Підкреслено важливість перетворення Данії зі слабкої ланки НАТО у минулому на важливого гравця нордичної та європейської оборони в наш час.

Ключові слова: Данія, блокова політика, НАТО, зовнішня політика, політика безпеки, політика застережень, холодна війна.

\section{Evolution of Denmark's Policy Towards the NATO in the Second Half of the $20^{\text {th }}$ Century}

The article focuses on Denmark's shifting approaches towards bloc policy through the lens of its security priorities. It emphasizes that the Danish exposure to security vulnerabilities is primarily due to its geographical location, which led to rejection of country's neutrality and to joining the NATO. The study stresses that internal factors have been continuously influencing the Danish defense policy, causing numerous controversies in domestic politics. Contradictions are identified in Denmark's efforts to preserve a balance between the status of a nuclear-free state and the need to accept the U.S. military base in Greenland. The reasons and peculiarities of the Danish ambivalent attitude towards the NATO during the Cold War are clarified. It is pointed out that a moderately independent approach to relations with the Eastern Bloc and efforts towards a further rapprochement was a prominent aspect of Denmark's security policy at that time. The study demonstrates that the Atlantic direction gradually lost its relevance in the Danish security policy after the NATO approved the «double solution» policy in 1979, which was based on nuclear rearmament and excessive demands towards the USSR in arms control negotiations. Denmark's approach to the NATO in the early 1980s was often described as «footnoting» and had a negative impact on Denmark's ally image in the North Atlantic Alliance. New geopolitical realities in the late 1980's pushed Denmark to adopt a more proactive security policy in the context of the Atlanticism. The nature of Denmark's participation in international security initiatives, intervention operations under the NATO auspices and US-led ad-hoc coalitions during the 1990's is thoroughly analyzed. The article underlines the importance of Denmark's transformation from a weak link within NATO into a significant Nordic and European security player.

Keywords: Denmark, bloc policy, NATO, foreign policy, security policy, footnoting, Cold War.

Постановка проблеми та її значення. Більшість дослідників наголошують, що нейтралітет був визначальною рисою зовнішньої політики Данії з кінця епохи Наполеона до іiі членства у

\footnotetext{
${ }^{1}$ Аспірантка факультету міжнародних відносин, Львівський національний університет імені Івана Франка, Україна. E-mail: ganushchakmv@ gmail.com; https://orcid.org/0000-0002-8129-5917.
} 
НАТО (1949 р. $)^{2}$. При цьому, виокремлюють три основні періоди у консолідації данської безпекової ідентичності. Перший, що тривав до кінця Другої світової війни, був пов'язаний із нейтралітетом Данії. Другий, який співпадав з періодом холодної війни, - обумовлювався членством Данії у НАТО та їі амбівалентною позицією щодо цієї організації. Данія здобула репутацію «непоступливого союзника», особливо наприкінці холодної війни ${ }^{3}$. Початок третього періоду припадає на час завершення міжблокового протистояння й трансформації НАТО. Відтоді данський безпековий дискурс відзначається універсалізмом, орієнтованим на Атлантизм ${ }^{4}$.

Справді, в умовах глобального протистояння двох наддержав не було периферії і не було можливостей діяти виключно в регіональному вимірі. Події, які розгорталися у безпосередньому сусідстві з Данією, не можна було розглядати без залучення глобального контексту. 3 огляду на це, Данія реалізувала прагматичний підхід «безпека понад усе», що пояснювалося розташуванням країни на передовій протистояння двох блоків під час холодної війни, з одного боку, та ідентичністю данської державності, - $з$ іншого. Згодом, на відміну від більшості європейських держав, Данія досить динамічно відреагувала на утвердження нового безпекового порядку, що став наслідком звільнення постсоціалістичних країн Східної Свропи і розпаду СРСР. Започаткована нова «активістська» зовнішня політика набула швидкого оформлення на доктринальному рівні. Її ключовими елементами стали спільна безпека, поширення демократії та захист прав людини. Сучасний стан інтенсивного залучення Данії у міжнародні безпекові процеси актуалізує вивчення контекстів становлення, змісту та еволюції безпекової політики цієї держави, особливо з огляду на чергове посилення безпекових викликів та загроз на Сході Європи.

Аналіз останніх досліджень і публікацій. Питання зовнішньополітичної активності державних акторів в безпековій сфері $є$ достатньо опрацьованим й уже тривалий час дискутується у науковій літературі. 3 огляду на значний теоретичний та прикладний інтерес, різні аспекти реалізації безпекової політики з боку окремих держав Європи також досить вичерпно представлені в сучасному політологічному дискурсі. Водночас, попри широкий спектр тематичної літератури (А. Вівель, Б. Геурлін, М. Келструп, Г. Нордквіст, Н. Петерсен, Б. Тернер), слід констатувати брак комплексних досліджень безпекової політики Королівства Данія, що однаковою мірою брали б до уваги експланативне обгрунтування її основних напрямів, а також проблемнохронологічні та просторово-орієнтовані складові.

Метою статті є розгляд політики Королівства Данії у НАТО під час холодної війни та безпосередньо після іiї завершення, як особливого прикладу реалізації національних пріоритетів й перетворення країни зі споживача на активного контрибутора міжнародної безпеки. Завданнями статті $є$ окреслити безпекові імперативи Данії, які визначали характер її блокової політики, прослідкувати еволюцію данських підходів щодо гарантування національної і міжнародної безпеки й висвітлити спільності та відмінності у безпековій діяльності країни під час та після завершення холодної війни. Досягнення мети й реалізація завдань статті досягаються шляхом застосування системного підходу й використання методів аналізу, синтезу та порівняння. Епістемологічною основою дослідження $є$ засади політичного реалізму та неореалізму.

Виклад основного матеріалу дослідження. Необхідність гарантувати безпеку Данії після Другої світової війни і можливість опинитися наодинці з потенційними загрозами з огляду на початок протистояння між Сходом і Заходом, поступово стали визначати данську безпекову політику. Данський уряд, усвідомивши вразливість держави, розпочав пошуки зовнішніх безпекових гарантій та шляхів закупівлі озброєнь. Спочатку він надав перевагу ідеї Нордичного оборонного союзу, який мав би здійснювати політику неприєднання ані до Заходу, ані до Сходу. Таку позицію, зокрема, обстоювали шведи. Вона була висунута на противагу норвезьким підходам, які передбачали створення блоку як союзного з Заходом. Фактично, норвежці вбачали у Нордичному оборонному союзі можливість стати частиною Північноатлантичного альян-

\footnotetext{
${ }^{2}$ Rieker P. (2006), “Denmark: reluctant adapter Europeanization of National Security Identity”, in: The EU and the changing security identities of the Nordic states, Abingdon: Routledge, p. 123.

${ }^{3}$ Einhorn E. (1975), “The Reluctant Ally: Danish Security Policy 1945-49”, Journal of Contemporary History, Vol. 10/3, pp. 493-512.

${ }^{4}$ Rieker P. (2006), op. cit., pp. 123-124.
} 
су, на що шведи не погоджувались. Сама ж Данія схилялася до шведського бачення, але була готова до будь-якого з компромісів, якого досягнули б шведи і норвежці 5 .

Проте уряд Норвегії уже в лютому 1949 р. вирішив, що такий варіант не гарантуватиме належного захисту і прийняв рішення на користь членства своєї країни у $\mathrm{HATO}^{6}$. Як зазначає Е. Айнгорн, Данії довелося відмовитись від ініціативи зі створення Нордичного оборонного союзу, оскільки данський уряд усвідомлював, що країни регіону, навіть об'єднавши власні зусилля і ресурси, не матимуть достатнього військового потенціалу для самостійної оборони․ Тому Копенгаген швидко погодився на американську ініціативу щодо створення НАТО у 1949 р. Таке рішення було, насамперед, обумовлено усвідомленням, що в умовах ізольованого нейтралітету та після поразки проекту Нордичного оборонного союзу, вступ до Альянсу залишився для Данії єдиною прийнятною альтернативою, яка давала змогу гарантувати національну безпеку. Цей крок означав, водночас, відмову данців від тривалої традиції нейтралітету ${ }^{8}$.

Період 1949-1961 рр. визначають як етап адаптації Данії у НАТО 9 . Це був час, коли Данії доводилося навчатися функціонувати у рамках багатостороннього альянсу та, водночас, брати участь у «великій грі» світових наддержав, хоча іiі роль і була незначною. Те, що Гренландія перебувала у складі Данії, відіграло ключову роль у зацікавлені цієї країною з боку США і вилилося у бажання залучити іiі у НАТО. Саму ж Данію американці розглядали як складну для оборони й, радше, як військовий тягар, а не як перевагу. 3 іншого боку, військові бази США у Гренландії підтвердили доцільність власного існування у роки Другої світової війни, а у післявоєнний період, за межами Північної Америки, їм відводили не менш важливе стратегічне значення, ніж Ісландії чи Азорським островам. США чітко заявили про прагнення зберегти американські військові бази у Гренландії під час двосторонніх перемовин 1947-1948 рр. і данський уряд, незважаючи на власне бажання скасувати угоду від 1941 р. й змусити американських військових залишити острів, пішов на поступки США ${ }^{10}$.

В угоді між Данією та США щодо оборони Гренландії (1951р.) не порушувалися питання ядерної зброї. Згодом, у листопаді 1957 р. прем’ер-міністр країни Г. Гансен жодним чином не відреагував на запит американського посла, який стосувався доцільності інформування уряду Данії про розміщення ядерної зброї на острові ${ }^{11}$. Фактично, в такий спосіб данці надали мовчазний дозвіл на довільну інтерпретацію американцями положень двостороннього договору. Це дало змогу перекинути у Гренландію американську ядерну зброю і відкрити їі повітряний простір для ядерних винищувачів.

Іншим чутливим питанням для Данії у цей час була взаємодія з ФРН. Наприклад, американські пропозиції, висунуті у жовтні 1950 р. про об'єднане військове командування, застали зненацька данський уряд, адже потенційно спричиняли низку проблем. По-перше, вони де-факто усували нечіткість формулювань статті 5 Північноатлантичного договору та зменшували простір для маневрування з боку держав-членів. По-друге, з огляду на те, що ФРН мала стати частиною об'єднаного командування, - нового звучання набувала німецька проблема, яка залишалася нездоланою травмою для данського політикуму впродовж століття ${ }^{12}$.

Слід наголосити, що у тогочасних реаліях створення об'єднаного командування НАТО у Європі було винятково важливим з погляду вразливості безпекової ситуації Данії, зумовленої. насамперед, іiі географічним розташуванням. Відтак, навіть озброєння Західної Німеччини і повторна поява на південних кордонах Данії німецьких військових формувань, розглядалися як прийнятні явища, адже глибша інтеграція усередині Північноатлантичного альянсу слугувала посиленню захисту супроти потенційної радянської агресії.

\footnotetext{
${ }^{5}$ Olesen T. (2001), “The Dilemmas of Interdependence Danish Foreign Policy 1945-1972”, Journal of European Integration History, Vol.7 (2), p. 49.

${ }^{6}$ Bjøl E. (1968), "NATO and Denmark", Cooperation and Conflict, Vol. 3, p. 94.

${ }^{7}$ Einhorn E. (1975), op. cit., p. 495.

${ }^{8}$ Doeser F. (2011), "Domestic politics and foreign policy change in small states: The fall of the Danish 'footnote policy", Cooperation and Conflict, Vol. 46 (2), p. 226.

${ }^{9}$ Petersen N. (1987), Denmark and NATO 1949-1987, Oslo: Forsvarsstudier, p. 14.

${ }^{10}$ Petersen N. (1987), op. cit., p. 17.

${ }^{11}$ Vestergaard C. (2014), "Going non-nuclear in the nuclear alliance: the Danish experience in NATO”, European Security, Vol.23 (1), p. 108.

12 Petersen N. (1987), op. cit., p. 15.
} 
Зауважимо, що поряд з Норвегією, жодна з європейських країн не надавала такого істотного значення безпеці Данії, як ФРН. Утім, двостороння співпраця з Німеччиною у військовій сфері сприймалася данцями зі застереженням. Ще з 40-х рp. XIX ст. Німеччина розглядалась як основна загроза для Данії, а у роки Другої світової війни данська територія була фізично окупованою Третім Рейхом. Окрім того, ФРН була єдиною державою-членом НАТО, яка мала неврегульоване питання кордонів 3 державами Варшавського договору і розглядалась як потенційне джерело для конфлікту в Свропі.

Водночас, 3'явилися інші дражливі питання, зокрема щодо формату німецько-данської військової співпраці. Хоча у Данії й було розуміння важливості німецьких військ для оборони країни, однак як кола данської еліти, так і пересічні громадяни із застереженням ставилися до щоденної взаємодії з бундесвером, адже йшлося не лише про співпрацю з колишнім ворогом, а й про його потенційне домінування у майбутньому.

Ключового значення у дансько-німецьких двосторонніх відносинах набула дискусія щодо організаційного підпорядкування німецьких військ у рамках НАТО. Також йшлося про низку інших аспектів. Наприклад, німці вимагали від данців розташування на території Данії складів iз військовим спорядженням, задля належного захисту південних кордонів країни. Зауважимо, що це питання було вирішено лише у 1960-х рр., коли таким об'єктам було надано статус інфраструктурних елементів НАТО.

3 метою уникнути потенційної недовіри, обумовленої складним історичним минулим, постачання німецьких військових 3'єднань у Шлезвіг-Гольштейні здійснювалося зі складів НАТО, розташованих на території Данії. Окрім цього, завдяки політичній волі було досягнуто компромісу, відповідно до якого територія німецького Шлезвіг-Гольштейну ставала частиною Командування ОЗС НАТО на підступах до Балтійського моря (англ. Allied Forces Baltic Approaches, БАЛТАП) із штаб-квартирою у данському місті Каруп. БАЛТАП завжди мав очолювати громадянин Данії ${ }^{13}$.

Слід згадати, що у дипломатичній ноті від 31 серпня 1961 р. радянський уряд попередив, що створення спільного командування може серйозно погіршити ситуацію у Балтійському регіоні і створити ситуацію, яка нестиме безпосередню загрозу безпеці СРСР. У цій ситуації Данія продемонструвала послідовність та непоступливість і у власній відповіді радянській стороні відкинула твердження про загрозу нової угоди безпеці СРСР, вказуючи на своє невід’ємне право забезпечувати власну оборону ${ }^{14}$.

Незважаючи на те, що у Данії традиційно були обмежені можливості впливу на опрацювання організаційних засад функціонування Північноатлантичного альянсу, у неї все ж було більше простору для дій, коли йшлося про практичне наповнення його діяльності. При цьому слід пам'ятати, що значний вплив на данську політику в сфері оборони мали внутрішні чинники і саме вона завжди викликала найбільше суперечок у політичному житті країни. Особливо чітко це спостерігалося у 1950-х рр. Зокрема, у 1950-1951 рр. данська оборона розбудовувалася шляхом фактичного узгодження внутрішніх застережень щодо витрат на оборону, питань фінансування й тривалості строкової служби із зобов'язаннями країни у рамках НАТО. Ці тренди збереглися й надалі, що було зумовлене кволим економічним зростанням країни ${ }^{15}$. У 1960 р. вдалося досягти історичного компромісу між урядом та опозиційними партіями з питань оборони і їх було знято з порядку денного Данії до кінця 1960-х рр. При цьому, згоди щодо поступового невеликого зростання бюджетних витрат на оборону досягти не вдалося ${ }^{16}$.

Загалом у період холодної війни витрати Данії на оборону були досить низькими, особливо у порівнянні з іншими партнерами по НАТО. Цей факт часто піддавався критиці з боку США ${ }^{17}$. Зокрема, Вашингтон звертав увагу Копенгагена на те, що недостатнє фінансування військових потреб може загрожувати трансатлантичним відносинам і згодом вплинути на якість оборони Данії у випадку зовнішньої агресії ${ }^{18}$.

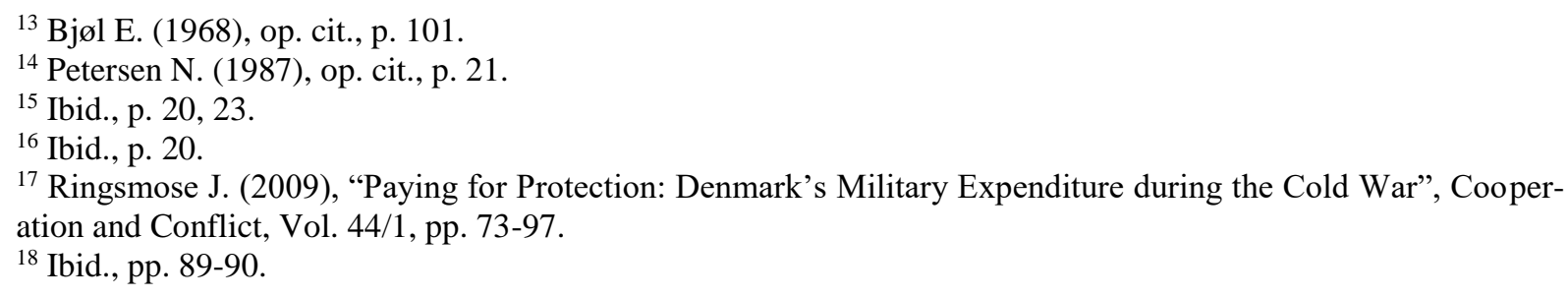


Зауважимо, що під час холодної війни Данія неодноразово демонструвала неготовність до участі в окремих ініціативах $\mathrm{HATO}^{19}$. Свідченням цього, зокрема, є три данські застереження щодо окремих кроків Альянсу. Перше з них пов'язане зі запитом США до Норвегії та Данії у 1950-1951 рр. щодо можливого розміщення на їхніх територіях авіаційних баз для військових винищувачів. Якщо Норвегія впровадила політику заборони іноземних баз на власній території ще до членства у НАТО, то Данія формально зробила це (за винятком Гренландії ${ }^{20}$ ) лише у 1953 р. Друге, - стосується данської відповіді на запровадження Альянсом нової доктрини масованої відплати, коли уряд країни заявив, що на території Данії не може буде розміщена ядерна зброя у мирний час ${ }^{21}$. Третє, - стосувалося заборони військових навчань на тих територіях, які Радянський Союз міг розглядати крізь призму стратегічних загроз для себе ${ }^{22}$. Водночас Копенгаген продовжував послідовно підтримувати політику НАТО щодо використання ядерної зброї, як одного з компонентів стратегії оборони альянсу.

Період 1962-1978 pр. визначають як етап консолідації данської безпекової політики ${ }^{23}$. Справді, на початок 1960-х рр. були напрацьовані ключові засади участі Данії у Північноатлантичному альянсі. Організаційна структура опиралася на об'єднане командування БАЛТАП, що функціонувало належним чином. Витрати країни на оборону хоч і повільно, проте постійно зростали. Досягнутий компроміс щодо оборони у 1960 р. забезпечив стабільність з цих питань у внутрішній політиці. Так само було досягнуто порозуміння щодо ядерної політики: наприкінці 1960-х рр. Данія стала постійним членом Групи ядерного планування Північноатлантичного альянсу ${ }^{24}$. Незважаючи на те, що данський вплив у цій структурі був незначним, країна все ж отримала доступ до цінної інформації і змогла краще опрацьовувати ядерну проблематику. До 1979 р., доки ядерні питання не почали політизувати у внутрішньо-державному дискурсі, участь Данії у цій структурі не викликала істотних заперечень.

Антимілітаризм та політика розрядки стали у цей період невід'ємною складовою із забезпечення миру ${ }^{25}$. При цьому слід пам'ятати, що геополітичне становище Данії було інакшим, ніж у нейтральних Швеції та Фінляндії, або члена НАТО - Норвегії, яка мала спільний кордон із СРСР. Тому з данських перспектив, обстоювання миру за допомогою політики розрядки було не настільки питанням національної безпеки, скільки спробою відстоювати ліберальноегалітарні цінності, властиві ідентичності країни ${ }^{26}$.

Примітним аспектом безпекової політики Данії у цей час було намагання відстоювати відносно незалежні підходи у відносинах зі Східним блоком й здійснювати кроки у напрямку розрядки, що згодом стали надбанням політики інших держав-членів HАTO $^{27}$. Зокрема, Данія налагодила відносини з СРСР та інтенсифікувала контакти 3 невеликими державами Східної Європи, як у двосторонньому форматі, так і у рамках «групи десяти». До останньої входили як держави-члени НАТО, так і учасниці Варшавського договору, а також нейтральні країни (Бельгія, Данія, Нідерланди, Болгарія, Румунія, Угорщина, Австрія, Фінляндія, Швеція, Югославія). Група була покликана дискувати пропозиції та ініціативи з питань європейської безпеки. Серед найпомітніших - створення без'ядерної зони на Півночі Свропи та проведення загальноєвропейської безпекової конференції. Остання ініціатива була пропозицію СРСР ще з 1954 р. Утім, коли ця ідея була представлена Данією на саміті НАТО у 1966 р. як прояв доброї волі, іï було

\footnotetext{
${ }^{19}$ Holbraad C. (1991), Danish Neutrality: A Study in the Foreign Policy of a Small State, Oxford: Clarendon Press, p. 108.

${ }^{20}$ Faurby Ib. (1995), "Danish Alliance Policy 1967-1993: From Quiet Adaptation via Loud Disagreement to Cautious Involvement", in Due-Nielsen C. and Petersen N. (Ed), Adaptation and Activism: The Foreign Policy of Denmark 1967-1993. Copenhagen: Jurist- ogØkonom for bundets Forlag, pp. 62-3.

${ }^{21}$ Holbraad C. (1991), op. cit., p. 134.

${ }^{22}$ Villaume P. (2000), "Denmark and NATO through 50 years", in Heurlin B. and Mouritzen H. (Ed.) Danish Foreign Policy Yearbook 1999. Copenhagen: Danish Institute of International Affairs, p. 37.

${ }^{23}$ Petersen N. (1987), op. cit., p. 29.

${ }^{24}$ Ibid., p. 31.

${ }^{25}$ Rasmussen M. (2005), "What's the Use of It?” Danish Strategic Culture and the Utility of Armed Force”, Cooperation and Conflict, 40(1), pp. 67-89.

${ }^{26}$ Jakobsen P. V. (1998), "The Danish Approach to UN Peace Operations after the Cold War: A New Model in the Making?", International Peacekeeping, Vol. 5(3), p. 107.

${ }^{27}$ Petersen N. (1987), op. cit., p. 29.
} 
прохолодно сприйнято іншими державами-членами. Розходження між союзниками зникли, коли у НАТО була прийнята доктрина Хармеля, що передбачала поєднання політики стримування 3 політикою розрядки.

Зміни 1960-х рр. у НАТО, пов'язані з заміною доктрини масованої відплати на доктрину гнучкого реагування й зосередження більшої уваги на політиці розрядки, позитивно вплинули на зростання прихильності у ставленні до альянсу з боку Данії ${ }^{28}$. Проте істотним випробовуванням данської лояльності щодо НАТО стало розгортання СРСР ракет СС20 у 1970-х рр ${ }^{29}$.

Восени 1979 р. було досягнуто домовленості про так зване подвійне рішення, відповідно до якого НАТО розпочала розміщення авіаносців та ракет Першінг II у Західній Європі, з метою протидії радянським ракетам СС20, пропонуючи, водночас, Радянському Союзу перемовини щодо скорочення озброєнь. У багатьох західноєвропейських країнах, де мали бути дислоковані ракети, почались акції протесту проти політики «подвійного рішення» ${ }^{30}$.

Ще перед самітом НАТО у грудні 1979 р. соціал-демократичний уряд Данії змінив свої позицію щодо політики «подвійного рішення». Зокрема, він пропонував відкласти ії запровадження на шість місяців, щоб дати час для початку перемовин із Радянським Союзом. Проте інші члени НАТО відкинули цю пропозицію ${ }^{31}$. Тому, незважаючи на застереження, данський уряд підтримав рішення альянсу. НАТО одноголосно схвалила політику «подвійного рішення» (1979 р.). Однак після 1981 р. стало зрозуміло, що СРСР не піде на перемовини.

Данія була лише опосередковано залучена у реалізацію «подвійного рішення» через надання фінансової підтримки ${ }^{32}$, однак іiі реакція на конфронтаційну політику США у безпековій сфері, що грунтувалася на ядерному переозброєнні та завищених вимогах до СРСР у перемовинах щодо контролю над озброєнням ${ }^{33}$, була, загалом, негативною. Адже безпекова політика Данії опиралася не на принцип стримування, а на міркування співпраці. Тому ця країна продовжувала активне залучення у розбудову НБСЄ, перетворившись, водночас, на стриманого члена $\mathrm{HATO}^{34}$. Фактично, на початку 1980-х рр. атлантичний напрям втратив важливість для данської безпекової політики.

Такий підхід Данії часто визначали як «політику застережень»-footnoting. Згодом з'явилося поняття «данізація», яке використовували $з$ метою вказати на обмежений внесок країни у спільно оборону та низький рівень ії бюджетних витрат на військові потреби, порівняно із союзниками ${ }^{35}$. Цим терміном послуговувалися також 3 метою окреслити держав-фрірайдерів усередині НАТО, що не бажали брати на себе частину солідарної відповідальності, хоча сповна користувалися усіма привілеями від членства та гарантіями безпеки ${ }^{36}$. Разом із «данізацією» у розумінні фрірайдерства, йшлося також про потенційну «фінлядизацію», як спосіб здійснення політики, що задовольняла би й не дратувала могутніших сусідів ${ }^{37}$.

\footnotetext{
${ }^{28}$ Due-Nielsen C. and Petersen N. (1995) "Denmark's Foreign Policy since 1967: An Introduction”, in DueNielsen C. and Petersen N. (Ed), Adaptation and Activism: The Foreign Policy of Denmark 1967-1993. Copenhagen: Jurist- ogØkonom for bundets Forlag. p. 15

${ }^{29}$ Doeser F. (2011), "Domestic politics and foreign policy change in small states: The fall of the Danish 'footnote policy",, Cooperation and Conflict, Vol. 46 (2), p. 227.

${ }^{30}$ Faurby Ib. (1995), "Danish Alliance Policy 1967-1993: From Quiet Adaptation via Loud Disagreement to Cautious Involvement", in in Due-Nielsen C. and Petersen N. (Ed), Adaptation and Activism: The Foreign Policy of Denmark 1967-1993. Copenhagen: Jurist-ogØkonom for bundets Forlag, p. 64.

${ }^{31}$ Holm Holm, H.-H. (1989), "A Democratic Revolt? Stability and Change in Danish Security Policy 19791989", Cooperation and Conflict Vol. 24, p. 184.

${ }^{32}$ Villaume P. (2000), "Denmark and NATO through 50 years", in Heurlin B. and Mouritzen H. (Ed.) Danish Foreign Policy Yearbook 1999. Copenhagen: Danish Institute of International Affairs, p. 42.

${ }^{33}$ Heurlin B. (2001), "Danish Security Policy over the Last 50 Years - Long-Term Essential Security Priorities", Working Papers 7, Copenhagen: DUPI, p. 10.

${ }^{34}$ Petersen N. (2000), "Adapting to Change: Danish Security Policy after the Cold War", in Hansen B. (Ed.), European Security, Copenhagen: Copenhagen Political Studies Press, pp. 99-116.

${ }^{35}$ Heurlin B. (1996), "Denmark: a new activism in foreign and security policy", in Hill Ch. (Ed.), The Actors in Europe's Foreign Policy, London: Routledge, p. 174.

${ }^{36}$ Heurlin B. (2001), op. cit., p.10.

${ }^{37}$ Petersson M. (2013), "Shifted Roles: Explaining Danish and Norwegian Alliance Strategy 1949-2009”, Journal of Strategic Studies, Vol.36(6), p. 776.
} 
3 перспектив Данії footnoting розуміли буквально як додавання критичних чи опозиційних коментарів до офіційних документів НАТО. Однак у широкому розумінні ця практика тлумачилось як відкрита незгода країни з позицією Північноатлантичного альянсу, незважаючи на те, чи їі виражали у форматі формальних приміток, чи ні ${ }^{38}$.

Дослідники вказують, що останнє десятиліття холодної війни було найдивнішим та найдраматичнішим в історії данської зовнішньої політики. Адже характер діяльності Данії у Північноатлантичному альянсі став істотно залежати від внутрішньої політики ${ }^{39}$, яка, в свою чергу, характеризувалася жорсткою опозицією до діяльності НАТО. При цьому, визначальним чинником були пріоритети парламентських політичних партій, що гостро критикували альянс за стратегію стримування та балансу сил ${ }^{40}$. Упродовж шести років було використано весь набір парламентського інструментарію, з метою взяти під контроль офіційну політику країни щодо НАТО. Останній охоплював надсилання запитів, слухання у комітетах, ухвалення парламентських рішень i, найголовніше, - проведення відкритих дебатів у парламенті за участю уряду ${ }^{41}$. Особливу роль у цьому контексті відіграла соціал-демократична партія Данії, яка зруйнувала попередній консенсус у внутрішній політиці країни. СРСР перестали трактувати як небезпеку, натомість увагу зосередили на двополюсному характері міжнародної системи і ядерній зброї, як основній загрозі ${ }^{42}$.

У 1982-1983 рр. парламент Данії звернувся до уряду країни із закликом припинити участь в інфраструктурних програмах НАТО, що залучені у підготовку до розгортання ракет. Також данський парламент наполягав, щоб ядерна зброя не розміщувалася на території країни не лише у мирний період, але й у випадку війни ${ }^{43}$. Тому уряд Данії був змушений виразно дистанціюватися від потенційного розгортання тактичної ядерної зброї на території країни, про що мало йтися на засіданні Комітету оборонного планування НАТО в червні 1983 р. Прем'єр-міністр П. Шлютер 3 цього приводу заявив, що таке рішення свідчитиме про завершення 34-річної співпраці з союзниками та перетворить Данію на маргінального члена Північноатлантичного альянсу ${ }^{44}$.

Саме з цієї події розпочинається відлік так званої політики застережень, яку Данія регулярно реалізувала в рамках НАТО до саміту у 1986 р. Фактично, у 1982-1986 рр. данський парламент спонукав уряд країни до внесення у підсумкові комюніке НАТО приміток про незгоду Данії 3 позицією Північноатлантичного альянсу. 3 часом застереження ставали більш конкретизованими, що надавало їм помітності та символізму, хоча насправді, ефективність приміток з данського боку залишалася сумнівною ${ }^{45}$.

Хоча підтримка членства Данії у Північноатлантичному альянсі залишилася всередині країни незмінною, наслідком внутріполітичних суперечок стало те, що чинник НАТО та вимоги трансатлантичної солідарності стали менше враховувати у парламентських процедурах 3 розгляду питань безпекової політики. Водночас, з погляду НАТО, Данія перетворилася на аутсайдера й зазнала маргіналізації усередині альянсу ${ }^{46}$.

Завершенню політики застережень сприяла зміна міжнародного становища, особливо після зустрічі М. Горбачова та Р. Рейгана у Рейк’явіку (1986р.) та підписання Договору про ліквідацію ракет середньої та малої дальності (грудень 1987 р.). Спостерігаючи за поступками 3

\footnotetext{
${ }^{38}$ Petersen N. (2012), "Footnoting" as a political instrument: Denmark's NATO policy in the 1980s", Cold War History, Vol.12 (2). p. 296.

${ }^{39}$ Petersen N. (2004), Europæisk og globalt engagement 1973-2003 [European and Global Engagement 19732003], Vol. 6, Dansk Udenrigspolitisk Historie [Danish Foreign Policy History], Copenhagen: Gyldendal Leksikon, p. 292.

${ }^{40}$ Petersen N. (2004), op. cit., p. 615.

${ }^{41}$ Petersen N. (2012), op. cit., p. 297.

${ }^{42}$ Nørgaard O. et al. (1995), "Danish Ostpolitik 1967-1993: Breakdown of Stability -Unknown Challenges", in Due-Nielsen C. and Petersen N. (Ed), Adaptation and Activism: The Foreign Policy of Denmark 1967-1993. Copenhagen: Jurist- ogØkonom for bundets Forlag, pp. 139-41.

${ }^{43}$ Holbraad, Carsten (1991) Danish Neutrality: A Study in the Foreign Policy of a Small State. Oxford: Clarendon Press 123

${ }^{44}$ Petersen N. (2012), op. cit., pp. 303, 309.

${ }^{45}$ Ibid., p. 298.

${ }^{46}$ Petersen N. (2004), op. cit., p. 616.
} 
боку Радянського Союзу, данський уряд був переконаний, що це стало наслідком консолідованої позиції НАТО, спрямованої на суттєве зниження протистояння на європейському континенті та у світі загалом. Тому для данського уряду було важливим не підважувати позиції альянсу. 3 травня 1987 р. уряд Данії відмовлявся від внесення застережень у комюніке НАТО, незважаючи на думку парламенту країни ${ }^{47}$.

Політика застережень вплинула, насамперед, на ядерну політику Данії й, водночас, не стосувалася американських баз, розміщених в Гренландії. Вона також не надто позначилася на політиці оборони цієї країни. Однак, після холодної війни, незважаючи на те, що політика застережень себе об'єктивно вичерпала, суперечки навколо неї не припинилися. Навіть були підготовлені чотири офіційні звіти, які містили спроби переосмислити цей етап данської історії.

Наприкінці 1980-х рр. новий данський уряд визнав необхідність докласти особливих зусиль з метою відбудувати довіру до Данії як до надійного міжнародного партнера. Основна стратегія передбачала залучення данців до розбудови європейського і глобального порядку, який би відповідав ліберальними принципам і цінностям. Ця стратегія була покликана об'єднати «чотири наріжні камені» (взаємодію з ООН, участь в СС, членство в НАТО та діяльність у Північній Раді.) зовнішньої та безпекової політики країни в єдине ціле, що отримало назву «активного інтернаціоналізму».

Насамперед, йшлося про політику «подвійного залучення». Вона, по-перше, передбачала першочергову увагу Данії до Центральної та Східної Європи, а також держав Балтії з метою нейтралізувати там потенційні загрози й створити зону безпеки, а, по-друге, - сприяння міжнародній співпраці шляхом створення комплексної інфраструктури для взаємодії старих i нових інститутів на регіональному та глобальному рівнях. Зокрема, завданням Данії було залучити у таку інфраструктуру сусідні постсоціалістичні країни задля створення європейської безпекової архітектури, яка базувалася б на багатосторонній співпраці і спільних безпекових зобов'язаннях.

У стратегії теж містилися елементи Realpolitik, що передбачали щонайтіснішу прив'язку Німеччини до $\mathrm{CC}$, з метою попередити загрозу ії домінування. Що стосується інтенсифікації європейських інтеграційних процесів, то данська дипломатія вказувала на необхідність активнішої зовнішньої політики, щоб відстоювати та ефективніше захищати інтереси Данії у нових багатосторонніх рамках та краще скористатися із об'єднавчих ініціатив. Загалом, політика активного інтернаціоналізму в цей час швидко перетворився на головний пріоритет країни ${ }^{48}$.

Не підлягає сумніву, що безпековий контекст Данії змінився істотніше, ніж у випадку інших нордичних країн, тому їй було порівняно простіше трансформувати власну безпекову доктрину $^{49}$. Данську політику безпеки було зосереджено на питаннях стабільності під час збройних конфліктів за межами країни, а також на боротьбі з тероризмом, що, на загал, кореспондувало 3 безпековими пріоритетами більшості країн-членів НАТО. Близьке партнерство зі США мало стати одним із інструментів, який дав би змогу уникнути маргіналізації Данії у нових реаліях, коли з об’єктивних причин у постбіполярному світі значимість Копенгагена для Вашингтона зменшилася ${ }^{50}$.

Данський політикум активно наполягав на інкорпорації ідеологічної складової у зовнішню політику країни. Зокрема, йшлося про поширення демократії, прав людини та ринкової економіки. Разом із більшою увагою до ліберальних цінностей змінювався і концепт суверенітету. У цьому контексті помітними стали парламентські дебати про зовнішню політику у листопаді 1992 р. Вони продемонстрували, що данський політикум трактував захист прав людини та національних меншин як глобальну відповідальність. Це вимагало перегляду політики невтручання у справи інших держав чи ролі гуманітарних інтервенцій.

\footnotetext{
${ }^{47}$ Doeser F. (2011), "Domestic politics and foreign policy change in small states: The fall of the Danish 'footnote policy"', Cooperation and Conflict, Vol. 46 (2), p. 231.

${ }^{48}$ Holm, H.-H. (2002) "The Rise and Decline of Foreign Policy Activism: The Case of Denmark", in Dahl A. and Hillmer N. (Ed), Activism and (Non)Alignment, Stockholm: Utenriks politiska institutet, pp. 83-102.

${ }^{49}$ Rieker P. (2006), "Denmark: reluctant adapter Europeanization of National Security Identity", in: The EU and the changing security identities of the Nordic states, Abingdon: Routledge, p. 128.

${ }^{50}$ Heurlin B. (2007), "Denationalisation of Danish Armed Forces and Militarising of Danish Foreign Policy. Denationalisation of Defence", Convergence and Diversity, pp. 118-21.
} 
Одним з перших ефектів від трансформації безпекового середовища Данії стала готовність цієї країни до підтримки миротворчих операцій. Хоча така позиція базувалася на традиційній для Копенгагена прихильності до ініціатив $\mathrm{OOH}$, однак зазнала розширення, охопивши також діяльність Данії як у НАТО, так і в рамках коаліцій на чолі зі США.

Символічно, що першим проявом данського міжнародного активізму стала участь країни у війні у Перській затоці, метою якої, саме на думку данського політикуму, було забезпечення дотримання принципів міжнародного права ${ }^{51}$. Це була перша збройна місія країни за межами європейського континенту, здійснена поза рамками $\mathrm{OOH}^{52}$. Ії успішна реалізація стала заслугою ліберального Міністра закордонних справ У. Еллеманн-Снсена, який тісно співпрацював із соціал-демократичним міністром оборони Г. Хеккерупом. Останній, зокрема, засуджував позицію власної партії за данську політику застережень у 1980-х рр. і прагнув компенсувати попередні репутаційні втрати Данії, намагаючись перетворити іiі на одного з найкращих союзників США.

У листопаді 1991 р. відбувся саміт НАТО в Римі, на якому була схвалена нова стратегічна концепція НАТО. У ній, зокрема, йшлося про необхідність збільшення мобільності збройних сил держав-членів, та скорочення часу їхньої поготови 3 метою краще реагувати на безпекові виклики. Данія позитивно відреагувала на ці зміни.

Данія реформувала власні збройні сили 3 метою забезпечити ефективнішу участь у міжнародних операціях. У грудні 1993 р. парламент країни схвалив пакет документів, які чітко визначали правові та організаційні аспекти майбутнього розгортання данських збройних сил. Для них було визначено три ключові операційні завдання. По-перше, спроможність долучатися до миротворчих, гуманітарних а також військових операцій самостійно або разом із НАТО у рамках мандату ООН та НБСС задля попередження чи врегулювання конфліктів. По-друге, участь в обороні Данії, що передбачає також діяльність 3 попередження та врегулювання потенційних конфліктів у сусідніх регіонах. По-третє, залучення у врегулювання конфліктів та оборону на території відповідальності усього Північноатлантичного альянсу, включаючи демонстрацію солідарності шляхом розгортання сил швидкого реагування ${ }^{53}$.

Після завершення холодної війни змінилось також розуміння того, що означає бути надійним членом НАТО. Хоча й надалі увага акцентувалася на солідарності держав-членів, проте все частіше істотним елементом стали визначати їхню спроможність долучатися до операцій з-поза географічних меж альянсу. Якщо у період холодної війни ключовими показниками були витрати на оборону й чисельність підготовлених військових, то в реаліях постбіполярного світу суттєвого значення набули можливість і готовність, а також кількість та якість особового складу, який може взяти участь у міжнародних операціях. Саме ці чинники визначають і сьогодні позицію держави у $\mathrm{HATO}^{54}$.

Зауважимо, що з перспективи західноєвропейських партнерів, які користувалися, до певної міри, привілейованим статусом у рамках НАТО, як Данія, чинник розширення альянсу міг призвести до подальшої маргіналізації їхніх позицій, адже зростала кількість членів, з якими взаємодіяли США. 3 іншого боку, розширення сприяло зміцненню та збільшенню ваги самої НАТО на міжнародній арені. Це потенційно зміцнювало вплив Данії, оскільки вона була частиною потужного військового блоку, що набував значимості. Окрім того, більшість нових країнчленів були проамериканськими й поділяли геополітичні преференції Данії 55 .

Утім, зміни в безпековій політиці Данії стали ще помітнішими, коли вона розпочала підтримувати ініціативи НАТО чи США, які не були схвалені з боку ООН. Це засвідчило прагнення данців відігравати помітнішу роль у Північноатлантичному альянсі, зокрема, через глибшу

\footnotetext{
${ }^{51}$ Pedersen R. (2012), op. cit., p. 337.

${ }^{52}$ Heurlin B. (2001), "Danish Security Policy over the Last 50 Years - Long-Term Essential Security Priorities", Working Papers 7, Copenhagen: DUPI, p.10.

53 Petersen N. (2000), “Adapting to Change: Danish Security Policy after the Cold War", in Hansen B. (Ed.), European Security, Copenhagen: Copenhagen Political Studies Press, pp. 99-116.

${ }^{54}$ Ringsmose, J. (2010). "NATO burden-sharing Redux: Continuity and change after the cold war", Contemporary Security Policy, Vol.31, pp. 319-338.

${ }_{55}$ Mouritzen H. (2006), “Atlantic reform: a Euro-Atlantic and a Danish perspective”, Danish Institute for International Studies REPORT. Vol. 3, p. 31.
} 
взаємодію країни зі Сполученими Штатами ${ }^{56}$. У цьому контексті події другої половини 1990x pp. на Балканах стали одним із викликів для трансформованої безпекової політики Данії. Адже під час конфлікту на території колишньої СФРЮ саме НАТО відіграла істотну, якщо не визначальну роль у його врегулюванні, що вимагало інтенсивного залучення держав-членів. Зокрема, у період косовської кризи Данія надала власні військові літаки (Ф-16), а ії̈ механізований батальйон брав участь у наземних військових операціях ${ }^{57}$.

Такий розвиток подій різко контрастував 3 подіями 1980-х рр., коли Данія остерігалася потенційного застосування сили з боку Північноатлантичного альянсу. Відтак створення Міжнародної бригади (1994р.) та участь країни у миротворчому контингенті НАТО на Балканах стали відображенням її прагнення до використання сили з огляду на нові реалії. Водночас, відданість Данії меті миротворчої місії на Балканах - забезпечити захист цивільного населення навіть в умовах відсутності мандату ООН, ілюструє примат ліберальних гуманітарних принципів у данській безпековій політиці, порівняно з питаннями непорушності суверенітету.

Дослідник К. Крістенсен виокремлює три чинники, що спонукають Данію до застосування військової сили у наш час: космополітичний, стратегічний та моральний ${ }^{58}$. Космополітичний чинник грунтується на переконанні, що використання Заходом сили - це універсальний інструмент захисту добра. Наприклад, повітряна кампанія у Сербії у 1999 р. була покликана припинити гуманітарну катастрофу у Косово. Стратегічний чинник у випадку використання Данією збройних сил пов'язаний з прагненням зберегти тісні союзницькі відносини зі США. Він проявляється, зокрема, у забезпеченні політичної і військової підтримки для американських ініціатив. Моральний чинник полягає у прагненні Данії компенсувати своєрідний негативний історичний спадок ії зовнішньої політики часів Другої світової війни й періоду міжблокового протистояння, який, серед іншого, стосується також деструктивної позиції країни в НАТО (1980i pp.).

Порівнюючи зовнішню політику Данії під час холодної війни і після неї, можна виокремити одну спільну рису та дві відмінності. Насамперед, присутній важливий елемент наступництва. Як тоді, так і сьогодні поширення данських цінностей $\epsilon$, радше, окремою метою, а не частиною гарантування національної безпеки ${ }^{59}$. Водночас, є два важливі елементи, що змінилися. У період холодної війни політика спрямована на забезпечення миру здійснювалась у тісній співпраці зі скандинавськими країнами та ООН. Сьогодні такими партнерами стали Сполучені Штати й НАТО. У період холодної війни політика Данії характеризувалася анти-мілітаризмом й, загалом, скептичним ставленням до наддержав. Сьогодні політика Данії щодо забезпечення миру передбачає активне використання військової сили у тісній співпраці зі світовою наддержавою - США.

Таким чином, після завершення міжблокового протистояння у данській зовнішній і оборонній політиці були присутні два ключові тренди. 3 одного боку, була очевидною готовність використовувати данські збройні сили у зонах конфліктів закордоном. 3 іншого, - данська зовнішня політика все більше пов'язувалася з мультилатералізмом. Обидва тренди реалізувалися на практиці, як, наприклад, активна участь Данії у миротворчих операціях НАТО та ООН на території колишньої Югославії. Окрім того, у рамках ООН Данія ініціювала створення багатонаціональних сил швидкого реагування SHIRBRIG. Вони вперше були використані для забезпечення припинення вогню між Ефіопією та Еритреєю у 2000 р. Участь у складі цих сил взяли також і данські військові ${ }^{60}$.

\footnotetext{
${ }^{56}$ Honkanen K. (2002), The Influence of Small States on NATO Decision-Making: TheMembership Experience of Denmark, Norway, Hungary and the Czech Republic, FOIR-0548-SE, Stockholm: Swedish Defence Research Agency, pp. 69-70.

${ }^{57}$ Petersson M. (2013), "Shifted Roles: Explaining Danish and Norwegian Alliance Strategy 1949-2009”, Journal of Strategic Studies, Vol.36(6), p. 771.

${ }^{58}$ Kristensen K. S., Larsen K. K. (2017), "Denmark's Fight Against Irrelevance, or the Alliance Politics of 'Punching Above Your Weight"', in Wesley M. (ed.), Global Allies. Comparing US Alliances in the 21st Century, Canberra: ANU Press, p. 69.

59 Wivel A. (2013), "From Peacemaker to Warmonger? - Explaining Denmark's Great Power Politics", Swiss Political Science Review. Vol.19(3), p. 309.

${ }^{60}$ Olsen G. (2007), "Denmark and ESDP", in Brummer K. (Ed.), The North and ESDP The Baltic States, Denmark, Finland and Sweden, Gütersloh, p. 27.
} 
Це слід вважати ключовою зміною у безпековій політиці Данії, частково зумовленою ії традиційною прихильністю до багатосторонньої співпраці у період холодної війни. Адже під час міжблокового протистояння Данія займала провідні позиції у сфері гуманітарної допомоги.

Висновки. Динаміка історичного розвитку перетворила Данію на малу державу, не забезпечивши належними засобами для самостійного виживання в несприятливому безпековому середовищі. Тому після завершення Другої світової війни саме в членстві у Північноатлантичному альянсі данці вбачали прагматичне вирішення проблеми безпеки власної країни. Утім, упродовж тривалого часу Данія була, радше, споживачем безпеки. Членство у НАТО часто розглядалося як «необхідне зло», прийнятний спосіб захисту національних безпекових інтересів, а не як інструмент забезпечення миру. Данія була інертним членом Північноатлантичного альянсу, починаючи з 1949 р., не відігравала істотної ролі в союзницькій політиці та перманентно зазнавала критики з боку США й Великої Британії за недостатній рівень власних витрат на оборону. У 1980-х рр. Данія почала активно використовувати «політику застережень» усередині НАТО, демонструючи, таким чином, власну незгоду зі жорсткою позицією США.

Уже на завершальному етапі холодної війни офіційні пріоритети данської закордонної і безпекової політик змінилися і серед данської еліти досить швидко утвердився консенсус щодо так званого «активного інтернаціоналізму». Безпрецедентно безпечне міжнародне середовище, у якому розвивалася Данія у той час, дало їй змогу зосередитися на опосередкованих викликах, 3 огляду на відсутність прямих загроз, що зникли після розпаду СРСР. Згодом Данія розпочала брати активну участь у миротворчих місіях різного характеру.

Данія успішно реформувала власні збройні сили й упродовж декількох років перетворилася зі слабкої ланки НАТО у важливого гравця нордичної та європейської оборони. Це пояснюється, серед іншого тим, що нові пріоритети Північноатлантичного альянсу відповідали данським традиційним зовнішньополітичним практикам. Зокрема, сприятливим чинником для участі Данії у миротворчих операціях, чи акціях з надання гуманітарної допомоги, стала послідовна прихильність країни до принципів багатосторонньої співпраці, що дала їй змогу набути статусу однієї з передових держав-членів НАТО у новій та динамічній міжнародно-політичній ситуації.

\section{References}

1. Bjøl E. (1968), "NATO and Denmark”, Cooperation and Conflict, Vol. 3, pp. 93-107.

2. Doeser F. (2011), "Domestic politics and foreign policy change in small states: The fall of the Danish 'footnote policy", Cooperation and Conflict, Vol. 46 (2), pp. 222-241.

3. Due-Nielsen C. and Petersen N. (1995) "Denmark's Foreign Policy since 1967: An Introduction", in Due-Nielsen C. and Petersen N. (Ed), Adaptation and Activism: The Foreign Policy of Denmark 1967-1993. Copenhagen: Jurist- ogØkonom for bundets Forlag.

4. Einhorn E. (1975), "The Reluctant Ally: Danish Security Policy 1945-49”, Journal of Contemporary History 10/3, pp. 493-512.

5. Faurby Ib. (1995), "Danish Alliance Policy 1967-1993: From Quiet Adaptation via Loud Disagreement to Cautious Involvement", in in Due-Nielsen C. and Petersen N. (Ed), Adaptation and Activism: The Foreign Policy of Denmark 1967-1993. Copenhagen: Jurist- ogØkonom for bundets Forlag.

6. Faurby Ib. (1995), "Danish Alliance Policy 1967-1993: From Quiet Adaptation via Loud Disagreement to Cautious Involvement", in in Due-Nielsen C. and Petersen N. (Ed), Adaptation and Activism: The Foreign Policy of Denmark 1967-1993. Copenhagen: Jurist- ogØkonom for bundets Forlag.

7. Heurlin B. (1996), "Denmark: a new activism in foreign and security policy", in Hill Ch. (Ed.), The Actors in Europe's Foreign Policy, London: Routledge, pp. 166-185.

8. Heurlin B. (2001), "Danish Security Policy over the Last 50 Years - Long-Term Essential Security Priorities", Working Papers 7, Copenhagen: DUPI.

9. Heurlin B. (2007), "Denationalisation of Danish Armed Forces and Militarising of Danish Foreign Policy. Denationalisation of Defence", Convergence and Diversity, pp. 113-134.

10. Holbraad C. (1991), Danish Neutrality: A Study in the Foreign Policy of a Small State, Oxford: Clarendon Press.

11. Holm, H.-H. (1989) "A Democratic Revolt? Stability and Change in Danish Security Policy 1979-1989”, Cooperation and Conflict Vol. 24, pp. 179-97. 
12. Holm, H.-H. (2002) "The Rise and Decline of Foreign Policy Activism: The Case of Denmark", in Dahl A. and Hillmer N. (Ed), Activism and (Non)Alignment, Stockholm: Utenriks politiska institutet, pp. 83-102.

13. Honkanen K. (2002), The Influence of Small States on NATO Decision-Making: TheMembership Experience of Denmark, Norway, Hungary and the Czech Republic, FOIR-0548-SE, Stockholm: Swedish Defence Research Agency, pp. 69-70.

14. Jakobsen P. V. (1998), "The Danish Approach to UN Peace Operations after the Cold War: A New Model in the Making?", International Peacekeeping, Vol. 5(3), pp. 106-123.

15. Kristensen K. S., Larsen K. K. (2017), “Denmark's Fight Against Irrelevance, or the Alliance Politics of 'Punching Above Your Weight'", in Wesley M. (ed.), Global Allies. Comparing US Alliances in the 21st Century, Canberra: ANU Press, pp. 59-70.

16. Mouritzen H. (2006), "Atlantic reform: a Euro-Atlantic and a Danish perspective", Danish Institute for International Studies REPORT. Vol. 3, 40 p.

17. Nørgaard O. et al. (1995), "Danish Ostpolitik 1967-1993: Breakdown of Stability - Unknown Challenges", in Due-Nielsen C. and Petersen N. (Ed), Adaptation and Activism: The Foreign Policy of Denmark 1967-1993. Copenhagen: Jurist- ogØkonom for bundets Forlag, pp. 139-41.

18. Olesen T. (2001), "The Dilemmas of Interdependence Danish Foreign Policy 1945-1972", Journal of European Integration History, Vol.7 (2), pp. 37-63.

19. Olsen G. (2007), "Denmark and ESDP", in Brummer K. (Ed.), The North and ESDP The Baltic States, Denmark, Finland and Sweden, Gütersloh, pp. 22-33.

20. Pedersen R. (2012), “Danish foreign policy activism: Differences in kind or degree?” Cooperation and Conflict, Vol.47 (3), pp. 331-349.

21. Petersen N. (1987), Denmark and NATO 1949-1987, Oslo: Forsvarsstudier, 48 p.

22. Petersen N. (2000), "Adapting to Change: Danish Security Policy after the Cold War", in Hansen B. (Ed.), European Security, Copenhagen: Copenhagen Political Studies Press, pp. 99-116.

23. Petersen N. (2004), Europæisk og globalt engagement 1973-2003 [European and Global Engagement 1973-2003], Vol. 6, Dansk Udenrigspolitisk Historie [Danish Foreign Policy History], Copenhagen: Gyldendal Leksikon.

24. Petersen N. (2012), "Footnoting" as a political instrument: Denmark's NATO policy in the 1980s", Cold War History, Vol.12 (2). pp. 295-317.

25. Petersson M. (2013), "Shifted Roles: Explaining Danish and Norwegian Alliance Strategy 1949-2009", Journal of Strategic Studies, Vol.36(6), pp. 761-788.

26. Rasmussen M. (2005), "What's the Use of It?" Danish Strategic Culture and the Utility of Armed Force", Cooperation and Conflict, 40(1), pp. 67-89.

27. Rieker P. (2006), "Denmark: reluctant adapter Europeanization of National Security Identity", in: The EU and the changing security identities of the Nordic states, Abingdon: Routledge, pp. 123150 .

28. Ringsmose J. (2009), "Paying for Protection: Denmark’s Military Expenditure during the Cold War", Cooperation and Conflict, Vol. 44/1, pp. 73-97.

29. Ringsmose, J. (2010). "NATO burden-sharing Redux: Continuity and change after the cold war", Contemporary Security Policy, Vol.31, pp. 319-338.

30. Vestergaard C. (2014), "Going non-nuclear in the nuclear alliance: the Danish experience in NATO”, European Security, Vol.23 (1), pp. 106-117.

31. Villaume P. (2000), "Denmark and NATO through 50 years", in Heurlin B. and Mouritzen H. (Ed.) Danish Foreign Policy Yearbook 1999. Copenhagen: Danish Institute of International Affairs.

32. Wivel A. (2013), "From Peacemaker to Warmonger? - Explaining Denmark's Great Power Politics", Swiss Political Science Review. Vol.19(3), pp. 298-321. 